\title{
PENINGKATAN HASIL BELAJAR PESERTA DIDIK MATA PELAJARAN EKONOMI DENGAN PENGGUNAAN METODE CERAMAH BERVARIASI
}

\author{
Oleh \\ Triana Susanti, ${ }^{*}$ Supardi**
}

\begin{abstract}
This study aims to: (1) describe the learning activities of students with the use of varied lecture methods with assignments and question and answer; (2) to find out the improvement in student learning outcomes in economic subjects with the use of lecture methods varies with the assignment of assignments and question and answer at Katingan Hilir Kasongan State Senior High School. The method in this study is qualitative and quantitative methods with the type of Classroom Action Research (CAR). Subjects in this study were students of class XI IPS with a total of 23 students. Data collection techniques in this study were using observation and tests. The data analysis technique in this study uses percentages. The results showed that: (1) with the use of lecture methods varied with assignments and question and answer students became more active, this was evidenced by the data obtained, namely in cycle I 2.5 and had entered the criteria enough and in the implementation of the second cycle of 2.9 and has achieved good criteria, (2) With the use of lecture methods vary with the assignment of tasks and question and answer, there is an increase in student learning outcomes. This can be seen from the percentage of student learning outcomes in the first cycle which is equal to 78 , $26 \%$, namely as many as 18 students who complete and in the implementation of the second cycle that is achieving class completeness where students who complete as many as 23 students or $100 \%$ complete. This means that the use of the lecture method varies with the assignment of assignments and question and answer can improve student learning outcomes on economic subjects.
\end{abstract}

Keywords: Improved learning outcomes, lecture methods vary.

$\begin{array}{ll} & \text { ABSTRAK } \\ \text { Penelitian ini bertujuan untuk: (1) mendeskripsikan aktivitas belajar peserta didik }\end{array}$ dengan penggunaan metode ceramah bervariasi dengan pemberian tugas dan tanya jawab; (2) untuk mengetahuipeningkatan hasil belajar peserta didik mata pelajaran ekonomi dengan penggunaan metode ceramah bervariasi dengan pemberian tugas dan tanya jawab di SMA Negeri I Katingan Hilir Kasongan. Metode dalam penelitian ini yaitu metode kualitatif dan kuantitatif dengan jenisPenelitian Tindakan Kelas (PTK).Subjek dalam penelitian ini yaitu peserta didik kelas XI IPS dengan jumlah peserta didik sebanyak 23 orang peserta didik.Teknik pengumpulan data dalam penelitian ini adalah dengan menggunakan observasi dan tes. Teknik analisis data dalam penelitian ini menggunakan persentase. Hasil penelitian menunjukkan bahwa: (1) dengan penggunaan metode ceramah bervariasi dengan pemberian tugas dan tanya jawab peserta didik menjadi lebih aktif, hal ini dibuktikan dengan datayang diperoleh yaitu pada siklus I 2,5 dan telah masuk dalam kriteria cukup dan pada pelaksanaan siklus II sebesar 2,9 dan telah mencapai kriteria baik, (2) Dengan penggunaan metode ceramah bervariasi dengan pemberian tugas dan tanya jawab, ada peningkatan hasil belajar peserta didik. Hal ini terlihat dari presentase hasil belajar peserta didik pada siklus I yaitu sebesar 78, 26\% yaitu sebanyak 18 peserta didik yang tuntas dan pada pelaksanaan siklus II yaitu mencapai ketuntasan kelas dimana peserta didik yang tuntas

Triana Susanti* Mahasiswa FKIP UM Palangkaaraya

Supardi** Dosen Universitas Muhammadiyah Palangkaraya 
sebanyak 23 orang peserta didik atau $100 \%$ tuntas. Ini berarti dengan penggunaan metode ceramah brvariasi dengan pemberian tugas dan tanya jawab dapat meningkatkan hasil belajar peserta didik pada mata pelajaran ekonomi.

Kata Kunci: Peningkatan hasil belajar, metode ceramah bervariasi.

\section{PENDAHULUAN}

Gambaran pendidikan dilihat dari teori pendidikan secara faktual adalah sekelompok orang dan guru yang melaksanakan kegiatan pendidikan untuk orang-orang muda dan secara perspektif memberi petunjuk bahwa pendidikan adalah muatan, arahan, pilihan yang telah ditetapkan sebagai wahana pengembangan masa depan anak didik yang tidak terlepas dari keharusan kontrol manusia. Pemahaman mengenai pendidikan mengacu pada konsep tersebut menggambarkan bahwa pendidikan seperti sifat sasarannya, yaitu manusia, mengandung banyak aspek dan sifatnya sangat kompleks. Karena sifatnya yang demikian kompleks itu, maka tidak suatu batasan pun yang cukup memadai untuk menjelaskan arti pendidikan secara lengkap.

Menurut Muhibynsyah (Jerry $\mathrm{H}$. Makawimbang, 2011:4) pendidikan diartikan sebagai sebuah proses dengan metode-metode tertentu sehingga orang memperoleh pengetahuan, pemahaman, dan cara bertingkah laku yang sesuai dengan kebutuhan. Sementara menurut $\mathrm{Ki}$ Hajar Dewantara (Jerry $\mathrm{H}$. Makawimbang, 2011:5) pendidikan adalah daya upaya untuk memajukan budi pekerti, pikiran serta jasmani anak, agar dapat memajukan kesempurnaan hidup yaitu hidup dan menghidupkan anak yang selaras dengan alam dan masyarakat. Johnson dalam Atwi
Suparman (Kasful Anwar \& Hendra Harmi, 2011:23) mendefinisikan "pembelajaran sebagai interaksi antara pengajar dengan satu atau lebih individu untuk belajar, direncanakan sebelumnya dalam rangka untuk menumbuh kembangkan pengetahuan, keterampilan, dan pengalaman belajar kepada peserta didik.

Menurut H.C. Witherington (Annurahman, 2012:35) mengatakan bahwa belajar merupakan tindakan dan perilaku peserta didik yang kompleks. Sebagai tindakan, maka belajarhanya dialami, dilakukan dan dihayati oleh peserta didik itu sendiri, dimana peserta didik adalah penentu terjadi atau tidaknya proses belajar, proses belajar terjadi berkat peserta didik memperoleh sesuatu yang ada di lingkungan baik itu berupa keadaan alam, benda- benda, hewan, tumbuh-tumbuhan, manusia, atau hal-hal yang dijadikan bahan belajar. Hakikat belajar dan pembelajaran adalah bahwa manusia selama hidupnya tidak akan lepas dari yang namanya belajar baik sekalipun dia telah selesai dalam menempuh pendidikan formal di sekolah. Sedangkan menurut Daryanto (2010:2) menyatakan bahwa belajar adalah proses usaha yang dilakukan dengan seseorang memperoleh suatu perubahan tingkah laku yang baru secara keseluruhan, sebagai hasil pengalamannya sendiri dalam interaksi dengan lingkungan. 
Menurut Kunandar (2011:251) menyatakan bahawa hasil belajar adalah kemampuan peserta didik dalam memenuhi suatu tahapan pencapaian pengalaman belajar dalam suatu kompetensi dasar. Dari pendapat tersebut maka dapat disimpulkan bahwa hasil belajar adalah suatu pencapaian yang diperoleh peserta didik melalui sebuah proses dengan tujuan khusus yang telah direncanakan. Sedangkan menurut Djamaluddin dan Abdullah Aly (Mastur Faizi, 2013) metode berasal dari kata "meta" berarti melalui dan "hodos" yang berarti jalan. Jadi metode adalah jalan yang harus dilalui untuk mencapai suatu tujuan.

Menurut Fathurahman (2007: 55) menyatakan bahwa metode adalah caracara menyajikan bahan pelajaran kepada peserta didik untuk tercapainya tujuan yang telah ditetapkan. Di Indonesia, metode kerap diartikan sebagai pendekatan, strategi, model, atau teknik pembelajaran, sehingga penggunaannya juga sering bergantian. Pada intinya metode merupakan suatu cara yang tepat dan cepat untuk meraih tujuan pendidikan, sesuai dengan kebutuhan peserta didik. Jadi metode merupakan suatu cara penyajian bahan pelajaran yang dilalui dalam mencapai suatu tujuan pembelajaran. Metode pembelajaran adalah seluruh perencanaan dan prosedur maupun langkah-langkah kegiatan pembelajaran termasuk pilihan cara penilaian yang akan dilaksanakan.

Dalam bukunya Abdul Azis Wahab (2009:88) menyatakan bahwa metode ceramah yang dalam istilah asing disebut 'lecture' berasal dari kata
Latin; lego (legere, lectus) yang berarti membaca. Kemudian lego diartikan secara umum dengan "mengajar" sebagai akibat guru menyampaikan pelajaran dengan membaca dari buku dan mendiktekan pelajaran dengan penggunaan buku kemudian menjadi "lecture method" atau metode ceramah. Menurut Syaiful Sagala (2012:200) adalah sebuah bentuk interaksi melalui penerangan dan penuturan lisan dari guru kepada peserta didik. Berdasarkan pendapat tersebut maka metode ceramah dapat diartikan sebagai penyajian bahan pelajaran secara lisan yang dilakukan dalam mencapai suatu tujuan pembelajaran. Penggunaan metode ceramah yang dikombinasikan atau divariasikan dengan metode lain yang saat ini dikenal dengan Metode Ceramah Bervariasi merupakan salah satu upaya meningkatkan kemampuan metode ceramah yang mulai dikenalkan pada saat upaya-upaya perbaikan dalam pendidikan di sekolah melalui Proyek Pengembangan Pendidikan Guru (P3G).

Metode ceramah bervariasi berarti cara penyampaian/penyajian bahan pelajaran dengan disertai macam-macam penggunaan metode pengajaran lain, seperti tanya-jawab dan diskusi terbatas, pemberian tugas dan sebagainya. Berdasarkan hal tersebut maka disimpulkanbahwa metode ceramah bervariasi diartikan sebagai cara penyampaian materi pembelajaran secara lisan yang disertai dengan pengunaan metode-metode lain sebagai pendamping atau dengan kata lain yang dimaksud metode ceramah bervariasi adalah penggunaan metode ceramah 
yang dikombinasikan dengan berbagai metode lainnya.

Berdasarkan uraian di atas,ditemukan masalah dalam belajarmata pelajaran ekonomi sehingga penulis tertarik untuk mengambil judul Peningkatan Hasil Belajar Peserta Didik Mata Pelajaran Ekonomi Dengan Penggunaan Metode Ceramah Bervariasi.

\section{METODE PENELITIAN}

Jenis penelitian ini yaitu Penelitian Tindakan Kelas(PTK) yaitu penelitian yang memiliki karakteristik mendeskripsikan semua informasi/data secara alamiah/apa adanya dan peneliti berperan sebagai instrumen penelitian, dan untuk rancangan dalam penelitian ini yaitu mengikuti rancangan model

Kemmis dan Mc Taggart (Samsu Somadayo, 2013:40) dengan empat tahapan yang harus dilalui untuk setiap siklusnya, yaitu; Perencanaan; Pelaksanaan Tindakan;

Observasi/Pengamatan; dan Refleksi

Dalam penelitian ini yang menjadi subjek penelitian adalah siswa-siswi kelas XI IPS dimana dalam satu kelas tersebut terdapat sebanyak 23 siswasiswi dengan komposisi 11 orang siswa laki-laki dan 12 orang siswi perempuan.

\section{HASIL PENELITIAN}

Berdasarkan pada data-data yang diperoleh dari hasil penelitian pembelajaran mata pelajaran ekonomi (akuntansi) siklus I dan siklus II di SMA Negeri 1 Katingan Hilir dengan jumlah peserta didik sebanyak 23 orang sebagai subjek penelitian. Data hasil penelitian yang dipaparkan yaitu berupa tes hasil belajar (tes awal, siklus I, dan siklus II). Tes hasil belajar dilakukan guna mengetahui ketuntasan peserta didik pada mata pelajaran ekonomi (akuntansi) setelah proses pembelajaran berlangsung. Secara terperinci data hasil penelitian siklus I dan siklus II dipaparkan sebagai berikut:

1. Hasil pengamatan aktivitas guru dan peserta didik

Hasil pengamatan terhadap aktivitas guru dan peserta didik dalam pembelajaran ekonomi pada SMA Negeri 1 Katingan hilir dengan menggunakan metode ceramah bervariasi dengan pemberian tugas dan tanya jawab menunjukkan perkembangan yang baik dimana pada siklus I nilai rata-rata yang diberikan pengamat untuk aktivitas guru yaitu 2,77 dan untuk aktivitas peserta didik yaitu 2,5 dan pada siklus II meningkat dengan penilaian rata-rata aktivitas guru yaitu 3,7 dn untuk aktivitas peserta didi yaitu 2,9.

2. Hasil belajar peserta didik

Hasil belajar peserta didik diperoleh dari data hasil tes awal nilai rata-rata peserta didik yang hanya memperoleh nilai rata-rata 67,60 nilai ini masih belum mencapai kriteria ketuntasan minimal yang ditentukan yaitu 70 . Hasil katuntasan belajar secara klasikal juga hanya memperoleh $52,17 \%$, sedangkan kriteria ketuntasan klasikal minimal 85\%.

Melalui pembelajaran menggunakan metode ceramah bervariasi dengan pemberian tugas dan tanya-jawab pada siklus I nilai rata-rata 
peserta didik mengalami peningkatan sebesar 71,74 dan telah mencapai kriteria ketuntasan minimal, akan tetapi secara klasikal belum mencapai $85 \%$. Pada siklus II nilai rata-rata peserta didik mengalami peningkatan cukup bagus dengan perolehan nilai rata-rata 80 dengan kriteria ketuntasan klasikal sebesar $87 \%$. Peneliti menganggap pada siklus II ini sudah berhasil karena telah mencapai nilai ketuntasan secara klasikal.

Berdasarkan data-data tersebut diatas dengan penggunaan metode ceramah bervariasi dengan tugas dan tanya jawab dapat meningkatkan aktivitas belajar dan hasil belajar peserta didik pada mata pelajaran ekonomimaka dengan demikianpenilitian ini mendukung penelitian terdahulu.

Adapun hasil penelitian terdahulu yang dilakukan oleh Rahmadani dimana metode yang dilakukan dapat meningkatkan hasil belajar siswa dengan presentase hasil belajar siswa dari siklus I ke siklus II meningkat 26\% dimana hal tersebut dapat dilihat dimana pada siklus I presentase ketuntasan peserta didik sebesar $74 \%$ dengan nilai rata-rata 74 dan pada siklus II presentase ketuntsan peserta didik adalah $100 \%$ dengan nilai rata- rata 81,71 . sebesar $47,82 \%$ dengan nilai rata-rata adalah 5,94 sedangkan pada siklus II presentase ketuntsannya yaitu sebesar 95,65 dengan nilai ratarata 7,29 .

\section{KESIMPULAN}

Berdasarkan hasil dari analisis data dan pengujian hipotesis yang telah dilakukan maka dapat disimpulkan bahwa:
1. Aktivitas belajar ekonomi peserta didik kelas XI IPS $^{3}$ di SMA Negeri 1

Katingan Hilir dengan penggunaan metode ceramah bervariasi dengan tugas dan tanyajawab lebih aktif/baik, hal ini dibuktikan dengan adanya peningkatan untuk aktivitas guru dan peserta didik, dimana pada siklus I untuk aktivitas guru kriteria yang dicapai sudah baik dengan nilai rata-rata untuk penilaian aktivitasaitu 2,77 sementara untuk aktivitas peserta didik hanya mencapai kriteria cukup baik dengan nilai rata-rata untuk penilaian setiap aktivitas yang dinilai yaitu sebesar 2,5 dan setelah dilaksanakan tindakan pada siklus II untuk aktivitas guru nilai rata-rata yang diperoleh meningkat menjadi 3,7 dan mencapai kriteria sangat baik dan aktivitas peserta didik pun meningkat dan masuk dalam kriteria baik dengan nilai rata-rata untuk setiap aktivitas yaitu sebesar 2,9 .

2. Ada peningkatan hasil belajar peserta didik kelas XI IPS $^{3}$ di SMA Negeri 1

Katingan Hilir dengan penggunaan metode ceramah bervariasi dengan tugas dan tanya jawab, hal ini dibuktikan dengan adanya peningkatan hasil belajar yang diperoleh peserta didik pada setiap tahap pembelajaran dimana pada tahap awal nilai rata-rata hasil belajar peserta didik sebesar 67,60 atau sebanyak 12 pesrta 
didik yang tuntas, sementara pada pelaksanaan siklus I meningkat menjadi 71,74 atau sebanyak 18 peserta didik yang tuntas, maka untuk nilai rata-rata peserta didik dari tahap awal ke siklus I meningkat sebesar $4,15 \%$ dan pada pelaksanaan siklus II nilai rata-rata hasil belajar peserta didik yaitu sebesar 87,60 atau sebanyak 23 peserta didik tuntas, maka nilai rata-rata peserta didik dari pelaksanaan siklus I ke siklus II meningkat sebesar $15,86 \%$.

\section{DAFTAR PUSTAKA}

Makawimbang, Jerry H. 2011. Supervisi dan Peningkatan Mutu Pendidikan. Bandung: Alfabeta.

Anwar, Kasful \& Harmi, Hendra. 2011. Perencanaan Sistem Pembelajaran. Bandung: Alfabeta.

Daryanto. 2010. Belajar dan Mengajar. Bandung: Yrama Widya.

Kunandar. 2011. Guru Profesional Implementasi Kurikulum Tingkat Satuan Pendidikan dan Sukses Dalam Sertifikasi Guru. Jakarta: Rajawali Pers.

Faizi, Mastur. 2013. Ragam Metode Mengajarkan Eksakta Pada Murid. Jogjakarta: Diva Press.

Wahab, Abdul Azis. 2009. Metode dan Model-Model Mengajar Ilmu Pengetahuan Sosial. Bandung: Alfabeta.

Sagala, Syaiful. 2012. Konsep dan Makna Pembelajaran. Bandung: Alfabeta.

Somadayo, Samsu. 2013. Penelitian Tindakan Kelas. Yogyakarta: Graha Ilmu. 